\title{
Analisis Pelaksanaan Community Relations GKI Pamulang Melalui Pelayanan Kesehatan untuk Masyarakat Sekitar
}

\author{
Sjilaa Qirsten Latuheru ${ }^{1}$ dan Sylvia Roennfeld ${ }^{2}$ \\ 1,2 Institut Komunikasi dan Bisnis LSPR, Jakarta, Indonesia
}

\begin{abstract}
ABSTRAK
Setiap organisasi harus membangun hubungan baik dengan masyarakat, termasuk organisasi social, demikian juga pada penelitian ini, yang akan membahas mengenai pelaksanaan community relations sebuah gereja, dalam hal ini GKI (Gereja Kristen Indonesia) Pamulang. Gereja GKI Pamulang menggunakan community relations untuk menyampaikan pesan bahwa kehadiran gereja tidak hanya untuk beribadah namun untuk membantu dan memberikan dampak positif bagi masyarakat. Tujuan dari penelitian ini, untuk mengetahui bagaimana pelaksanaan community relations GKI Pamulang melalui bidang kesehatan yaitu LPM Lentera untuk masyarakat. Penelitian ini menggunakan 9 langkah program public relations yang di kemukakan oleh Ronald Smith, dengan metode penelitian yang digunakan adalah kualitatif, dimana data yang didapat diperoleh melalui wawancara dan dokumentasi.
\end{abstract}

Kata kunci: program; community relations; masyarakat; gereja; kesehatan

\begin{abstract}
Every organization must build good relations with the community, including social organizations. As in thisresearch, which will discuss the implementation of community relations in a church, in this case GKI (Indonesian Christian Church) Pamulang. As a church, GKI feels that community relations is able to convey the message that the church's presence is not only to worship but to help and have a positive impact on the community. And the purpose of this research is to find out how the implementation of the community relations of GKI Pamulang through health is LPM Lentera for the community. To find out the implementation of this research using 9 steps public relations program. The method used is qualitative. The data obtained is obtained through interviews and documentation.
\end{abstract}

Keywords: program; community relations; society; church; health

\section{PENDAHULUAN}

Pamulang sebuah kecamatan di Tangerang Selatan. Awalnya Pamulang merupakan bagian dari kecamatan Ciputat, yang kemudian mengalami pemekaran, pada tahun 1993 (sekilas Kecamatan Pamulang, tangerangselatankota.go,id, 2017). Pamulang pada mulanya dihuni oleh orang Betawi yang mayoritas beragama Islam. Namun seiring dengan perkembangan jaman, orang-orang Betawi mulai berkurang, dan mulai banyak orang- orang dari berbagai daerah yang tinggal di Pamulang. Masyarakat di Pamulang terdiri dari berbagai macam budaya dan agama. Berbagai macam agama dianut oleh warga pamulang mulai dari Islam, Kristen, 
Katholik dan Buddha. Namun mayoritas agama di Pamulang masih tetap dipegang oleh agama Islam. Agama terbanyak kedua ialah Kristen, pada tahun 1980 mulai banyak warga Kristen yang bermukim di Pamulang (Sejarah singkat GKI Pamulang, gki-pamulang.org, n.d).

Tabel 1. Jumlah Penduduk Berdasarkan Agama di Kecamatan Pamulang

\begin{tabular}{lr}
\hline Agama & Jumlah \\
\hline Islam & 266.895 \\
\hline Kristen & 17.603 \\
\hline Katolik & 7.019 \\
\hline Hindu & 818 \\
\hline Budha & 1.773 \\
\hline Konghuchu & 270 \\
\hline & $\mathbf{2 9 4 . 3 7 8}$
\end{tabular}

Sumber: Dinas Kependudukan dan Pencatatan Sipil Tangerang Selatan, 2017

Jumlah penduduk Kristen di Pamulang saat ini mencapai kurang lebih 17.603 jiwa (Dinas Kependudukan dan Pencatatan Sipil Tangerang Selatan, 2017). Namun demikian banyak sekolah Kristen ataupun panti asuhan Kristen yang didirikan di Pamulang. Dengan banyaknya orang Kristen yang bermukim di Pamulang, maka mulai banyak juga gereja-gereja yang didirikan. Hal tersebut dapat dilihat mulai dari Pamulang 1 saja telah terdapat 8 gereja. Ditambah dengan gereja yang berada di Pamulang 2 dan sekitaran Pamulang lainnya. Mulai dari gereja Katolik sampai dengan gereja Protestan yang terbagi lagi menjadi beberapa jenis gereja.

Gedung gereja di Pamulang ada yang memiliki gedung sendiri ataupun di pertokoan. Namun letak gereja-gereja ini juga tidak sedikit yang berada di sekitaran perumahan. Bahkan seperti yang dialami gereja-gereja di Indonesia pada umumnya, persyaratan mendirikan gereja banyak dan membutuhkan waktu yang lama untuk memenuhinya, sedangkan kebutuhan ibadah umat Kristen dilakukan setiap minggunya. Pada awalnya saat Pamulang belum seramai sekarang, masalah pendirian gedung gereja tidak hanya mengenai perizinan, namun ternyata diketahui adanya penolakan oleh beberapa warga Pamulang yang tidak bisa menerima dengan adanya gereja di sekitar tempat tinggal penduduk. Hal ini di alami beberapa gereja yang sudah berdiri sejak lama di Pamulang, diantaranya ialah GBKP Pamulang (Gedung ini telah didirikan serta digunakan selama 10 tahun, namun kemudian diprotes warga (Gereja yang Telah Digunakan Lebih dari 10 tahun Diprotes Warga, 2014, n.n), gereja katolik Santo Barnabas (mengalami penolakan oleh warga yang tergabung dalam FPAI, dan adanya berita yang beredar bahwa Gereja Katolik Paroki Rasul Barnabas merupakan gereja Katolik terbesar di Asia-Tenggara, dan yang terakhir ialah GKI Pamulang (yang harus mengalami perpindahan lokasi ibadah beberapa kali). Ketiga gereja diatas merupakan contoh-contoh kasus gereja di tolak oleh masyarakat. GKI Pamulang awalnya menggunakan gudang suatu PT yang direnovasi dan digunakan untuk beribadah umat Kristen (Sejarah singkat GKI Pamulang, gki-pamulang.org, n.d). Karena letak gedung tersebut berada di perumahan Pamulang Permai I, lalu diketahui adanya warga yang merasa keberatan dengan keberadaan GKI Pamulang. Dengan demikian 
PT tersebut menukar tanah tersebut dengan lahannya terpencil dan jauh dari pemukiman warga Pamulang (Sejarah singkat GKI Pamulang, gki-pamulang.org, n.d).

Pelayanan rohani yang dilayankan bagi umat Kristen Protestan di Pamulang, dilakukan melalui beberapa program GKI seperti PA (pendalaman Alkitab), persekutuan, dan lain sebagainya. Sedangkan pelayanan masyarakat sekitar khususnya dalam bidang kesehatan dilaksanakan melalui Balai Pengobatan. (Sejarah singkat GKI Pamulang, gki-pamulang.org, n.d).

GKI Pamulang menggunakan Balai Pengobatan ini sebagai sarana juga untuk menjalin hubungan baik dengan masyarakat serta komunitas disekitaran gereja. Dimana sebagai sebuah organisasi yang berada di tengah masyarakat, gereja perlu menjalin komunikasi yang baik dengan masyarakat sekitar. Komunikasi yang dilakukan dengan tujuan mencapai pemahaman hubungan baik (community relations) ini tidak hanya perlu dibangun tapi juga dibina agar setiap kegiatan gereja (organisasi) didukung oleh masyarakat sekitar.

Community Relations adalah program pengembangan komunitas yang melalui berbagai upaya untuk kemaslahatan bersama bagi organisasi dan komunitas. (Devita, esaunggul.ac.id, 2010). Dan menurut Iriantara dalam jurnal 3 mahasiswa Universitas Katolik Widya Mandala Surabaya, bahwa community relations tidak dapat terpisahkan dengan corporate social responsibility (Sinaga, wima.ac.id, 2015).

Community Relations dapat dilakukan melalui kegiatan-kegiatan sosial atau masuk dalam isuisu publik. Kegiatan sosial bisa berupa pelayanan sosial. Pelayanan sosial merupakan program yang memberikan pertolongan atau perlindungan kepada masyarakat yang kurang beruntung (Setiyawati, media.neliti.com, n.d). Pelayanan sosial bisa menjadi salah satu upaya meningkatkan kesejahteraan sosial (Sulistiowati, journal.student.uny.ac.id, 2015). Community relations yang dilakukan tidak hanya sebatas memberikan bantuan agar sebuah orgnaisasi dapat diterima masyarakat, namun bagaimana organisasi mampu memberikan pemahaman mengenai bantuan yang mereka berikan. Karena dalam memberikan bantuan, masyarakat yang menerima akan memiliki pertanyaan mengenai bagaimana mereka bisa dan mengapa harus percaya dengan bantuan yang mereka dapatkan. Perlunya pemahaman yang diberikan melalui community relations akan berdampak pada citra dan reputasi organisasi / perusahaan. Ada beberapa contoh kasus yang terjadi apabila community relations tidak ada ataupun tidak dibina dengan masyarakat, diantaranya; (a) Gereja Toraja Jemaat Maranu, (b) GKI Yasmin.

Community relations ini akan mampu mempengaruhi resistensi masyarakat, seperti; dimana penolakan bisa berubah menjadi penerimaan. Dimana mejalankan community relations merupakan tugas public relations transfer process, dimana ignorance menjadi knowledge, hostility menjadi sympathy dan prejudice menjadi acceptance. Dengan adanya community relations yang berjalan baik mampu menunjukan bahwa hubungan baik yang berhasil dibina oleh suatu organisasi atau perusahaan dengan masyarakat sekitar. Sebuah organisasi melakukan community relations tidak hanya untuk dapat diterima oleh masyarakat, melainkan adanya pesan-pesan yang juga ingin disampaikan. Salah satu bentuk menjalin hubungan baik dapat melalui pemberian layanan sosial. Layanan sosial yang diberikan juga biasanya, seperti; memberikan layanan kesehatan dan pendidikan/beasiswa kepada orang-orang yang 
membutuhkan. Layanan Sosial merupakan kegiatan yang terorganisir dengan tujuan untuk membantu masyarakat yang membutuhkan dan menyesuaikan diri dengan lingkungan (Salingbagi, salingbagi.com, 2014).

GKI Pamulang sebagai sebuah gereja memiliki kegiatan sosial untuk masyarakat sekitar, diantaranya adalah; (a) memberikan pelajaran agama Kristen untuk anak-anak Kristen yang sekolah di sekolah negeri dan tidak ada pelajaran agama Kristen, (b) adanya pelayanan di Panti Werda/Jompo, (c) adanya dana orang tua asuh bagi masyarakat umum yang membutuhkan dana anak sekolah, dan (d) GKI Pamulang membuat Balai Pengobatan Lentera.

Dengan adanya fenomena seperti diatas, peneliti tertarik untuk mengkaji bagaimana pelaksanaan community relations GKI Pamulang dalam membina hubungan dengan masyarakat sekitar. Community relations merupakan fokus dalam penelitian ini, sesuai dengan judul penelitian yaitu "Analisis Community Relations GKI Pamulang melalui pelayanan kesehatan untuk masyarakat sekitar". Dimana peneliti ingin meneliti mengenai hubungan baik yang terjalin antara GKI Pamulang dengan masyarakat sekitar.

Menurut W. J. Peak dalam buku Public Relations the Profession and the practice; Community relations, as a public relations function, is an institutions planned, active, and continuing practicipation with and within a community to maintain and enhance its environment to the benefit of both the institution and the community (Lattimore, 2007, p.224). Jadi community relations merupakan kegiatan partisipasi perusahaan yang berkelanjutan untuk memelihara dan meningkatkan lingkungan demi kepentingan perusahaan dan masyarakat.

Contoh membangun hubungan baik dengan komunitas, misalnya dengan memberikan bantuan dana bagi keluarga atau penduduk yang kurang mampu, memberikan beasiswa kepada anakanak kurang mampu dan lain sebagainya. Namun kegiatan community relations tidak hanya organisasi yang dapat membantu komunitas, namun komunitas juga dapat membantu organisasi. Karena program community relations juga dapat membantu dalam perekrutan karyawan dan memberi pengaruh perusahaan dalam urusan masyarakat (Wilcox, 2005, p.331). Komunitas atau masyarakat dengan lembaga/perusahaan, hidup saling bergantung satu sama lain, karena perusahaan tidak dapat hidup apabila tidak ada dukungan dari masyarakat (Moore, 2004, p.415).

Dewasa ini sebuah komunitas mengalami perubahan keinginan terhadap organisasi yang berada disekitar mereka. Organisasi yang hadir disekitar mereka diharapkan mampu memberikan bantuan secara permanen yang mampu meningkatkan taraf hidup masyarakat setempat (Iriantara, 2004, p.36). Misalnya seperti dalam penelitian ini akan dibahas mengenai kegiatan community relations dimana kegiatan tersebut bersifat permanen untuk masyarakat setempat. Community relations bisa menjadi alat bagi suatu organisasi atau perusahaan dalam menyesuaikan diri dengan lingkungan atau masyarakat sekitar, serta menghadapi tekanan yang akan atau sedang dialami suatu organisasi.

Ada beberapa langkah dalam menentukan tujuan pembuatan program community relations 
perusahaan, diantaranya (Lattimore, 2007, p.226-228); (1) mengetahui siapa masyarakat atau komunitas di sekitar perusahaan, (2) berkomunikasi dengan masyarakat atau komunitas setempat, dan (3) tentuan media untuk berkomunikasi dengan masyarakat tersebut.

\section{Nine Step of of Strategic Public Relations (Program Public Relations)}

Dalam penelitian ini, yang akan diteliti ialah kegiatan community relations dari GKI Pamulang, dimana kegiatan tersebut merupakan program Public Relations, oleh sebab itu penelitian ini didasari dengan Nine Steps of Strategic Public Relations by Ronald Smith. 9 step of strategic PR ini merupakan langkah-langkah membuat sebuah program PR. Pada nine step strategi public relations terdapat empat fase yang akan diuraikan menjadi sembilan langkah, yaitu;

\section{Format Penelitian}

\section{Tahap 1: Analisis Situasi}

Pada awalnya, perlu dilakukan analisis mengenai situasi mengenai daerah atau tempat berlangsungnya kegiatan community relations tersebut. Guna mengetahui adanya hambatan/kendala serta kesempatan yang bisa dicapai oleh perusahaan/organisasi saat melaksanakan program (Smith, 2013, p.11).

Tahap 2: Analisis Organisasi

Dalam langkah ini, mengharuskan peneliti untuk melakukannya secara hati-hati dan berdasarkan pada aspek organisasi seperti; (1) lingkungan internal (misi, kinerja dan sumber daya, (2) adanya persepsi publik (reputasi), dan (3) lingkungan eksternal (pesaing dan lawan, serta pendukung) (Smith, 2013, p.11).

Tahap 3: Analisis Publik

Analisis publik adalah bagaimana kita menganalisa target publik dari Lentera yang akan tertarik dengan pelayanan kesehatan ini. Dimana kita perlu menganalisa kepada siapa pesan yang akan kita sampaikan, masyarakat yang bagaimana yang akan tertarik dengan program atau pesan yang disampaikan (Smith, 2013, p.12).

\section{Strategi}

\section{Tahap 4: Objective}

Langkah ini adalah langkah untuk menganalisa secara jelas, spesifik dan terukur untuk menentukan tujuan kegiatan community relations tersebut. Apakah tujuan perencanaan ini untuk menyadarkan masyarakat atau membuat masyarakat mau merespon secara emosional (menerima) atau bertindak sesuai publik (Smith, 2013, p.12).

Tahap 5: Merumuskan Kegiatan dan Respon Strategi

Pada langkah ini perencana akan mempertimbangkan apa yang akan kita lakukan dalam berbagai situasi. Karena pada setiap perencanaan akan selalu mempertimbangkan segala sesuatu sesuai dengan sasaran dan tujuan. (Smith, 2013, p.12).

Tahap 6: Mengembangkan Pesan Strategi

Analisa mengenai bagaimana mengkomunikasikan pesan dengan baik, mulai dari siapa yang akan mejelaskan pesannya, dalam bentuk apa saja mempublikasiannya. Serta cara berdialog yang mampu mempersuasi target publik. (Smith, 2013, p.12).

Step 7: Memilih Taktik Komunikasi

Tahap ini adalah tahap memilih cara atau alat komunikasi yang baik, sesuai dengan setiap pesan 
atau masalah yang menjadi fokus utama perencanaan ini.

Tahap 8: Melaksanakan Rencana Strategis

Pada tahap ini perencana membuat implementasi dari setiap strategi yang telah direncanakan, sesuai dengan tujuannya masing - masing. Serta merencanakan dan menjelaskan anggaran yang diperlukan (Smith, 2013, p.13).

\section{Penelitian Evaluatif}

Step 9: Mengevaluasi Rencana Strategi

Pada tahap ini perencana membuat evaluasi serta penilaian segala aspek yang telah dijalankan sesuai tujuan, Serta memastikan terpenuhi atau tidaknya tujuan utama perencanaan program tersebut (Smith, 2013, p.13).

\section{Teori Komunikasi Persuasif}

Penelitian ini menggunakan teori Komunikasi Persuasif, karena penelitian ini menganalisis komunikasi GKI Pamulang yang mempersuasi target atau masyarakat yang dituju. Komunikasi Persuasif adalah komunikasi yang bertujuan mengubah atau mempengaruhi kepercayaan, sikap, dan perilaku seseorang sehingga bertindak sesuai dengan yang diharapkan oleh komunikator (Suryanto, 2015, p.354). Dan sikap individu atau dalam hal ini masyarakat dapat dipengaruhi oleh 3 hal, yaitu; (1) kognitif atau perilaku masyarakat yang mencapai atau mulai mengetahui objek yang di perkenalkan (Suryanto, 2015, p.355), (2) afektif atau perilaku masyarakat yang mulai memiliki kecenderungan untuk suka atau tidak suka terhadap objek yang sudah diketahui (Suryanto, 2015, p.355), dan (3) konatif atau perilaku yang masyarakat sudah sampai pada tahap melakukan sesuatu terhadap objek tersebut (Suryanto, 2015, p.355).

Terdapat unsur - unsur komunikasi persuasif pada pelaksanaan community relations GKI Pamulang melalui layanan kesehatan untuk masyarakat ini. Unsur - unsur ini menurut Aristoteles ada 3 unsur, yaitu; (1) Persuader. Persuader adalah sumber komunikasi, orang atau sekelompok (sebuah badan organisasi) yang menyampaikan pesan dengan tujuan untuk mempengaruhi sikap, pendapat, dan perilaku orang lain baik secara verbal maupun nonverbal (Suryanto, 2015, p.357); (2) Persuade. Persuade yang adalah penerima komunikasi, orang atau sekelompok orang yang menjadi tujuan penyampaian dan penyaluran pesan oleh persuader, secara verbal ataupun nonverbal (Suryanto, 2015, p.357); dan (3) Efek komunikasi. Efek komunikasi persuasif atau perubahan yang terjadi pada penyampai pesan sebagai akibat dan diterimanya pesan melalui proses komunikasi, efek yang terjadi berbentuk perubahan sikap pendapat dan tingkah laku (Suryanto, 2015, p.357).

\section{METODE PENELITIAN}

Dalam penelitian yang berjudul Analisis Community Relations GKI Pamulang melalui Layanan Kesehatan Untuk Masyarakat, metode yang digunakan ialah metode kualitatif dan studi deskriptif. Menurut Prof. Dr. Sugiyono, metode kualitatif adalah metode penelitian yang digunakan untuk meneliti kondisi obyek yang alamiah, metode ini seringkali disebut sebagai metode naturalistic karena penelitiannya dilakukan pada keadaan yang alami (2009, p.1). 
Pendekatan kualitatif dibangun berdasarkan tradisi pemikiran Jerman yang lebih banyak mengadopsi pemikiran filsafat plato humanistis (Bungin, 2007, p.3). Metode yang digunakan dalam penelitian ini ialah metode deskriptif. Dimana metode deskriptif digunakan untuk meneliti kegiatan - kegiatan, pandangan ataupun proses yang sedang berlangsung dan berpengaruh dari sebuah fenomena (Nazir, 2003, p.55). Metode kualitatif fokus pada proses bagaimana suatu fenomena terjadi dan berdasarkan asumsi (Creswell, 2013, p.206).

Sedangkan menurut Karin Klenke, penelitian kualitatif merupakan proses penyelidikan naturalistik yang mencari pemahaman mendalam tentang fenomena sosial dalam setting atau konteks naturali mereka (Klenke, 2016, p.6). Dengan demikian metode ini digunakan peneliti karena sesuai dengan keterangan para ahli yaitu metode ini digunakan untuk meneliti kegiatan atau proses yang berpengaruh dari sebuah fenomena.

\section{HASIL DAN PEMBAHASAN}

\section{FORMATIVE RESEARCH}

\section{Analisis Situasi}

Situasi Pamulang saat itu masih minim tempat beribadah untuk umat Kristen dan sebagai kaum minoritas seringkali tidak mudah untuk melaksanakan ibadah. Maka GKI sebagai gereja harus mampu masuk kemasyarakat dan GKI memilih kesehatan, untuk dapat masuk kemasyarakat, yang dimana saat itu klinik kesehatan masih minim di Pamulang.

\section{Analisis Organisasi}

GKI Pamulang tidak membatasi, bahkan ingin berhubungan dengan segala kalangan umur, agama, dan tingkatan ekonomi.

\section{Analisis Publik}

Target publik yang ingin disasar ialah masyarakat secara umum, tanpa ada batasan usia, agama, dan tingkatan ekonomi. Dengan angka data kunjungan pasien yang cukup menunjukan tingginya kunjungan pasien ke Klinik Lentera, hal ini juga memperlihatkan bahwa GKI Pamulang mulai bisa masuk ke masyarakat. Sesuai harapan Lentera juga bahwa Lentera tidak ditujukan hanya untuk masyarakat sekitar atau pihak eksternal GKI, namun juga dapat digunakan untuk jemaat GKI Pamulang atau internal GKI Pamulang. Ditambah dengan pelayanan yang diberikan Lentera sangat ramah dan membuat semua pasien yang datang nyaman dan mampu membuat hubungan baik diantara GKI melalui Lentera dengan masyarakat.

\section{STRATEGY}

\section{Goals \& Tujuan}

Kehadiran GKI Pamulang tidak mengganggu ataupun merugikan masyarakat dan atau lingkungan sekitar, melainkan memberikan dampak positif bagi lingkungan sekitar. Terutama melalui layanan kesehatan yang diberikan Lentera, yang dianggap bisa berdampak kesegala usia. 


\begin{abstract}
Aksi \& Respon
GKI Pamulang menyediakan fasilitas klinik, seperti; peralatan medis untuk perawatan gigi, obat-obatan generic, menyediakan tempat atau gedung dan lain sebagainya. Penggunaan obatobat generic tersebut dianggap murah namun baik untuk dikonsumsi (Adie Rambu, wawancara data primer, 27 April 2018). Dalam penyediaan klinik, GKI Pamulang memanfaatkan gedung gereja yang lama. Hal ini diketahui berdasarkan hasil pengamatan peneliti dan wawancara dengan karyawan Lentera yaitu ibu Adie Rambu.
\end{abstract}

Selain itu, pada pelaksanaannya menggunakan obat-obat generic yang murah namun baik untuk dikonsumsi (Adie Rambu, wawancara data primer, 27 April 2018). Hal ini sesuai juga yang dirasakan dengan pasien - pasien yang berkunjung.

Untuk dapat menjangkau masyarakat secara langsung, GKI Pamulang memanfaatkan anggota jemaat, baik itu yang berprofesi sebagai dokter atau yang memiliki kemampuan mengorganisir kegiatan ini.

GKI Pamulang juga berusaha untuk memberikan layanan yang baik. Sesuai dengan tujuan utama GKI Pamulang ialah memberikan pelayanan kesehatan. Tentu pelayanan yang diberikan perlu diimbangi dengan adanya pelayanan dari orang-orang yang ramah dan membuat para pasien nyaman

Dalam menyebarkan informasi mengenai klinik Lentera, GKI Pamulang faatkan karyawan untuk melakukan hal tersebut. Penyebaran informasi ini menggunakan word of mouth. Hal ini sesuai dengan pengakuan salah satu karyawan Lentera yang merupakan karyawan pertama Lentera.

GKI Pamulang membentuk kepengurusan untuk mencari tahu dan mengelola pelayanan yang akan diberikan pada masyarakat, sebelumnya akhirnya tercetus LPM Lentera. GKI Pamulang juga membuat program yang dapat berinteraksi langsung dengan masyarakat. Dengan memanfaatkan para relawan Lentera untuk dapat berinteraksi dengan masyarakat di perkampungan sekitar Pamulang.

\title{
Penggunaan Komunikasi yang Efektif
}

Menggunakan berbagai program antara lain; Lentern of Soul untuk mengenalkan Lentera ke jemaat GKI Pamulang, sekaligus mencari dana, Lentera Peduli yaitu pelaksanaan penyuluhan atau workshop yang memberikan informasi mengenai pencegahan penyakit, serta senam pagi Bersama dengan mengundang pasien, masyarakat sekitar, dan jemaat untuk berolah-raga bersama.

\section{Tactic}

\section{Menentukan Taktik Komunikasi}

Dalam merealisasikan kegiatan yang mampu membina hubungan baik GKI Pamulang dengan masyarakat sekitar, maka strategi yang telah dibuat perlu didukung dengan taktik untuk dapat menjalankannya, diantaranya; penyediaan fasilitas oleh GKI Pamulang. Penyediaan fasilitas tersebut termasuk merenovasi gedung gereja lama, untuk dijadikan klinik tempat berobat yang 
layak, menyediakan dokter-dokter yang memiliki surat izin praktik yang dikeluarkan dari Pemerintah, penyediaan alat-alat medis yaitu alat yang membantu pemeriksaan dan pengobatan penyakit.

Alat-alat yang disediakan tersebut antara lain dental unit (alat cabut gigi, scaling, tambal gigi), LCD untuk check gigi, Stetoskop, Tempat tidur pasien, alat cek gula darah, kolestrol, asam urat, alat nebulizer (inhalasi pasien batuk dan flu), alat kebidanan (papsmear dan iva test), ruang tunggu, TV untuk pasien diruang tunggu, Timbangan, Alat tensi, dan lain sebagainya.

GKI Pamulang juga turut menyediakan obat generik yang diperoleh dari supplier obat yang mereka gunakan sudah terpercaya dan harganya sudah sesuai dengan keuangan Lentera.

Selain itu GKI Pamulang memaanfaatkan anggota jemaat mereka. Dalam hal ini GKI Pamulang melibatkan jemaat dalam kepengurusan ataupun menjadi karyawan di Lentera. Keterlibatan tersebut dapat dilihat dari bukti foto- foto pelantikan pengurus dan beberapa volunteer berikut. Dimana para pengurus Lentera ini dilantik dihadapan jemaat GKI Pamulang.

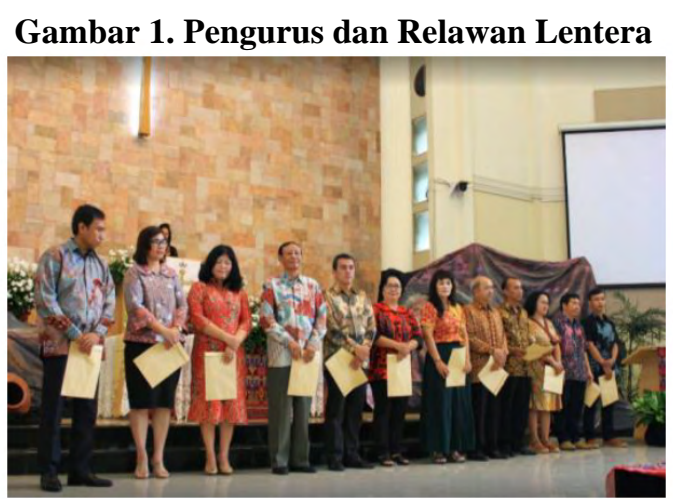

Sumber: Dokumentasi Penelitian, 2015

GKI Pamulang juga terus berupaya untuk memberikan layanan yang baik kepada masyarakat seperti terlihat pada gambar di bawah ini.

Gambar 2. Pemeriksaan Pasien

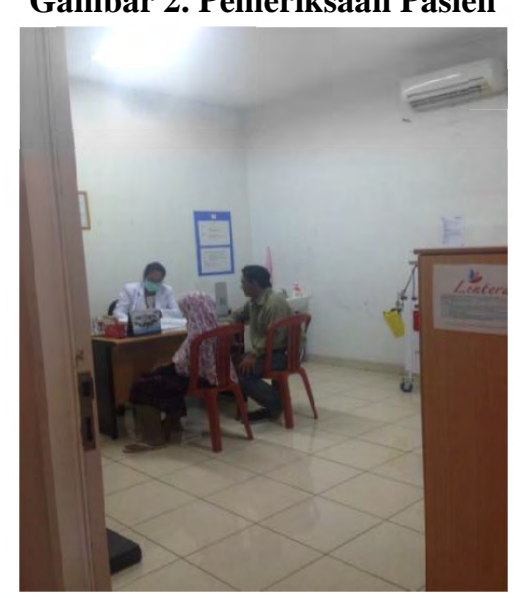

Sumber: Dokumentasi Penelitian, 2018 
Tentu pelayanan yang diberikan perlu diimbangi dengan adanya pelayanan dari orang - orang yang ramah dan membuat para pasien nyaman. Suasana kekeluargaan yang diciptakan oleh pengurus maupun kepala kantor Lentera ini, memang menjadi hal penting bagi GKI, dan menjadi utama yang diberikan juga untuk setiap pasien yang datang, tanpa melihat status ataupun SARA. GKI Pamulang juga melakukan upaya memanfaatkan karyawan sebagai penyalur informasi. Hal ini dapat dilihat dari pengakuan para karyawan yang selalu menginformasikan adanya Lentera kepada masyarakat. "Ya saya setiap ketemu siapapun di Pamulang, entah itu tukang ojek saya selalu infoin adanya Lentera” (Adie Rambu, wawancara data primer, 27 April 2018).

GKI Pamulang membentuk kepengurusan untuk mencari tahu dan mengelola pelayanan yang akan diberikan pada masyarakat, sebelumnya akhirnya tercetus LPM Lentera. Kelompok ini pada mulanya melakukan survei masyarkat, untuk mencari tahu mengenai kebutuhan masyarakat Pamulang. Karena GKI Pamulang tidak hanya harus memberi apa yang dibutuhkan masyarakat, namun harus menyesuaikan dana yang dimiliki GKI saat itu.

Upaya lain yang dilakukan oleh GKI Pamulang adalah dengan membuat program yang dapat berinteraksi langsung dengan masyarakat. Program tersebut ialah program Lentera Peduli. Lentera Peduli merupakan kegiatan penyuluhan mengenai info kesehatan. Dan penyuluhan ini ada yang dilakukan untuk komunitas-komunitas atau orang-orang yang berada di perkampungan Pamulang. Yang dimana komunitas tersebut kebanyakan beranggotakan ibuibu (dr. Iona Aipassa, wawancara data primer, 9 Maret 2018). Sementara taktik komunikasi yang digunakan masih tradisional, yaitu melalui; flyer, word of mouth, iklan di majalah Gema GKI Pamulang, dan website GKI Pamulang.

\section{Pelaksanaan Strategi}

Peneliti menyimpulkan bahwa pelaksanaan strategi ini memang dilakukan sesuai dengan prosedur atau aturan yang ada, dan segala sesuatunya dipersiapkan dengan matang. Layanan kesehatan ini diberikan dengan segala fasilitasnya tidak hanya didasari oleh keinginan ingin menjalin hubungan baik, tapi disesuaikan dengan kemampuan GKI Pamulang, baik dari segi dana maupun sumber daya manusianya.

\section{Evaluation}

Pada bagian evaluasi ini akan dijelaskan mengenai bagaimana GKI Pamulang melakukan evaluasi terhadap klinik Lentera. Dimana evaluasi ini berguna untuk membantu GKI Pamulang memperbaiki kesalahan atau kekurangan yang terdapat saat Klinik Lentera beroperasi. Evaluasi ini tidak hanya untuk memperbaiki tapi juga bisa untuk membuat program-program baru yang dirasa perlu. Dan menurut dr. Max sebagai mantan kepala kantor Lentera, "Evaluasi dilakukan tidak hanyak teknis tapi juga mengenai program - program yang mungkin dapat menimbulkan program-program baru yang memang dirasa perlu" (dr. Max, wawancara data primer, 25 mei 2018). 
Ada beberapa catatan evaluasi pada setiap upaya GKI Pamulang menjalin hubungan dengan masyarakat. Dalam menyediakan fasilitas ini memang hambatannya didana yang harus bertahap untuk dapat memberikan fasilitas lengkap. Selain itu dalam program Lentera Peduli terjadi penurunan angka pada komunitas yang menjadi target, dari 12 menjadi 8 komunitas. "Tumbuh atau jatuh nya programnya tergantung mereka," (dr. Max, wawancara data primer, 25 Mei 2018). Namun kegiatan ini diberikan GKI Pamulang melalui Lentera tanpa mengharapkan apa-apa, dan sifatnya tidak memaksa.

Sebagai organisasi sosial GKI Pamulang menyadari bahwa saat melibatkan jemaat dasarnya adalah pelayanan, bukan uang atau gaji. Pengurus Lentera GKI Pamulang perlu membuat suasana pelayanan yang baik dan kekeluargan. Dimana hal ini merupkan kunci utama para sukarelawan bisa bertahan. Dalam memberikan pelayanan yang baik ini GKI Pamulang menerapkan untuk bisa diberikan secara kekeluargaan kepada pasien. Termasuk saat pasien selalu tidak membawa kartu anggota atau kartu BPJS, sebagai pelayan karyawan atau suster di klinik Lentera harus mampu sabar dan tetap ramah untuk mencarikan data pasien tersebut. GKI Pamulang menggunakan para karyawan GKI ataupun Lentera untuk menyebarkan informasi mengenai Lentera. Dalam hal ini teknik penyebaran informasi akan lebih ditinggkatkan. Mulai akan menggunakan media sosial para karyawan.

\section{Analisis Hambatan Pelaksanaan Community Relations GKI Pamulang melalui Pelayanan Kesehatan-Lentera}

Dalam pelaksanaan sebuah kegiatan, pasti ada kendala atau hambatan yang dialami, apalagi kalau kegiatan tersebut bersifat berkelanjutan dan berhubungan dengan banyak orang. GKI Pamulang pun untuk masuk ke masyarakat, memiliki hambatan atau kendala yang dialami sejak awal ataupun yang sedang dialami. Hambatan-hambatan tersebut adalah dalam menyediakan setiap fasilitasnya dibeli sesuai dengan anggaran yang ada saat itu ataupun adanya sumbangan dari jemaat atau donatur. "Karena kita kan perlu menyesuaikan dengan dana kita" "kita kan hidup dari donatur" - (Ibu One, wawancara data primer, 29 Agustus 2018) Dikarenakan Lentera berdiri berdasarkan donatur, maka untuk setiap fasilitas Lentera akan terpenuhi secara bertahap. Seperti yang selalu dikatakan Ibu One selaku kepala kantor Lentera saat ini.

Dalam melibatkan jemaat GKI Pamulang dalam kegiatan sosial GKI Pamulang ini bisa dikatakan cukup banyak yang tertarik. Namun untuk proses mengajak tidak cepat. Terutama untuk jemaat - jemaat yang berusia muda, masih sangat kurang. Sesuai dengan yang dikatakan oleh ibu One saat rekrutmen volunteer. "Waktu bazaar kemarin kita mau rekrut volunteer yang muda-muda ya, tapi mungkin belom tertarik ya, karena kerjaan ini tuh tidak hasilnya apa-apa, tapi kerjaan ini harus continue, harus cerewetkan"- (Ibu One, wawancara data primer, 29 Agustus 2018).

Dalam membentuk kepengurusan Lentera, diakui pihak GKI sedikit sulit dan butuh waktu yang lama. Tidak hanya mengenai saat pencariannya, namun dalam perjalanannya memang seringkali juga banyak kesulitan dalam hal waktu. Hal ini dapat dilihat dari evaluasi yang dilakukan oleh pengurus dalam jangka waktu yang panjang. Seperti yang diakui oleh dokter 
Max Sabandar, dokter dan perintis Lentera. "Cuma memang untuk evaluasi-evaluasi yang sifatnya tidak mendesak itu dilakukan 1 kali dalam tiga tahun sesuai dengan pergantian Pergantian Pengurus Lentera." (dr. Max Sabandar, wawancara data primer,25 Mei 2018). GKI melalui pengurus mengharapkan untuk setiap suster dan atau karyawan Lentera tidak membawa persoalan dari luar Lentera dalam arti terbawa emosi dan lain sebagainya. "Saya selalu bilang kalau lagi ada masalah dikeluarga atau persoalan diluar Lentera, mohon jangan dibawa kemari” - (One, wawancara data primer, 29 Agustus 2018).

Dalam membuat kegiatan Lentera Peduli ada beberapa hambatan yang terjadi dari dalam dan luar Lentera. Dimana hambatan yang dari dalam Lentera ialah sumber daya manusia untuk menyampaikan materi atau pesan kesehatan. "Dari dulu itu itu terus motivatornya", "sepuh sepuh lagi udah, dulunya sih ada bapak-bapaknya, cuma mungkin sibuk ya”- (Ibu One, wawancara data primer, 29 Agustus 2018). Lalu kendala lainnya berasal dari pihak eksternal. Dimana angka komunitas yang dikunjungi semakin berkurang. Mulanya angka komunitas yang dikunjungi 12 dan sempat menurun menjadi 8 komunitas. Hal ini dikarenakan dikarenakan orang-orang dikomunitas tersebut tidak bisa atau ada kegiatan lain di kampung tersebut.

\section{Analisis Upaya mengatasi Hambatan Pelaksanaan Community Relations GKI Pamulang melalui Pelayanan Kesehatan-Lentera}

Segala hambatan yang dialami GKI untuk dapat memberikan layanan kesehatan ini, karena adanya evaluasi maka ada upaya yang dilakukan GKI Pamulang untuk mengatasi hal tersebut. Dalam penyediaan fasilitas seperti tempat, peralatan medis, dokter dan lain-lain, GKI Pamulang melalui pengurus Lentera selalu mengupayakan yang terbaik. Namun kembali pada kesediaan dana yang berasal dari donatur, maka Lentera untuk memperbaharui atau menambah fasilitasnya perlu waktu yang bertahap. Upaya uang diusahakan saat ini Lentera sedang mendata ulang donatur yang sudah pernah menyumbang dan atau akan menjadi calon donatur. Adanya hubungan yang kembali dibangun melalui kontak dan adanya jasa yang bertugas untuk menjalin hubungan dengan para donaturnya

Dalam mencari sumber daya manusia GKI Pamulang menggunakan cara-cara seperti; a) dari mulut ke mulut, b) menghubungi ketua komisi di GKI Pamulang untuk menyebarkan info, c) lalu warta baca saat ibadah minggu, d) booth Lentera di setiap ibadah minggu. Hal ini dilakukan terutama dalam mencari volunteer.

Untuk menjadi pengurus Lentera dilakukan pencarian oleh pengurus sebelumnya. Proses yang dilakukan oleh GKI adalah dengan mengajak secara pribadi untuk menjadi pengurus. Dengan kata lain ajakan menjadi pengurus ini secara dari mulut ke mulut. Tidak ada persyaratan khusus untuk menjadi pengurus Lentera.

Lentera selalu berupaya memberikan yang terbaik dan cara yang baik kepada pasien yang datang. Maka performa atau kinerja setiap suster dan karyawanpun sangat diperhatikan oleh kepala kantor ataupun pengurus Lentera. Pihak GKI Pamulang melalui pengurus atau kepala kantor Lentera selalu menegur dan mengingatkan mengenai hal ini saat briefing pagi atau saat evaluasi. Untuk hambatan dari internal Lentera ialah kekurangan tenaga yang usia muda. 
Upaya yang dilakukan Lentera adalah dengan membuka stand recruitment saat bazaar di gereja.

Berikut adalah upaya yang dibuat GKI Pamulang untuk mengatasi hambatan-hambatan yang terjadi ;

\section{Lentern of Soul (Charity Night)}

Lantern of Soul merupakan acara malam dana sekaligus untuk memperkenalkan Lentera ke jemaat GKI Pamulang (internal GKI Pamulang). Dimana dalam acara ini jemaat diajak untuk mengetahui kegiatan Lentera dan segala kebutuhannya, serta mengajak jemaat untuk berbagi dengan masyarkat sekitar melalui Lentera.

\section{Program Pasien Asuh}

Program Pasien Asuh ini dibuat untuk membantu pasien-pasien yang tidak mampu membayar obat atau biaya pemeriksaan di dokter sesuai tarif normal Lentera. Program ini telah berjalan sekitar 10 tahun, yang terdaftar menjadi pasien asuh cukup banyak dan sudah berganti-ganti.

"Untuk pasien asuh ini sudah 10 tahun, untuk orangnya berganti-ganti, dan sekarang kita lagi mulai tawarkan lagi untuk donator-donaturnya, untuk mengaktifkan donaturnya. Dan ini tidak tertutup untuk pasien atau calon donaturnya dari luar gereja” (dr. Iona Aipassa, wawancara data primer, 9 Maret 2018).

Dan menurut kepala Lentera, program ini sangat membantu pasien - pasien Lentera yang kebanyakan adalah masyarakat kurang mampu. Untuk para donatur pasien asuh ini, biasanya dari orang-orang GKI Pamulang yang dianggap mampu dan mau menjadi donatur untuk Pasien Asuh. Donatur tersebut juga tidak hanya selalu dari orang atau jemaat GKI Pamulang, bisa juga orang-orang dari luar gereja. Namun program ini perlu perhatian dan admin yang selalu mengkonfirmasi dan mendata para donatur dan pasien asuhnya. Pada awal 2018 ini, Lentera mulai mendata ulang pasien dan donaturnya, karena sempat mengalami penurunan. Dengan adanya program ini diharapkan dapat membantu GKI Pamulang dan Lentera untuk bisa tetap memberikan layanan kesehatan ini, dan agar hubungan baik antara GKI dengan masyarkat tetap terjalin.

Evaluasi untuk pembentukan kepengurusan ini tidak banyak dibicarakan oleh pihak GKI ataupun Lentera karena memang pemilihan para pengurus ini berdasarkan sukarela dan niat melayani sesuai yang diajarkan agama Kristen atau gereja.

\section{SIMPULAN}

Sesuai dengan hasil penelitian yang telah dilakukan dan dibuat oleh peneliti mengenai pelaksanaan community relations GKI Pamulang melalui pelayanan kesehatan untuk masyarakat sekitar, maka dapat disimpulkan bahwa GKI Pamulang telah menyelenggarakan kegiatan community relations melalui beberapa tahapan seperti pada ulasan sebelumnya.

Formative Research 
GKI Pamulang merupakan salah satu gereja yang mampu bertahan dan menciptakan suasana yang baik dengan masyarakat sekitar. Tidak ada batasan target untuk publik yang disasar, terutama usia. Sesuai dengan misi GKI ingin memberikan pelayanan kepada masyarakat pada seluruh lapisan usia. Niat baik GKI Pamulang tersebut disambut baik oleh masyarakat sekitar, dengan bertambahnya angka pengunjung atau pasien yang datang berobat ke Lentera.

\section{Strategy}

Hubungan baik ini dibangun oleh GKI Pamulang melalui beberapa pemberian pelayanan kesehatan dengan strategi; (a) memberikan fasilitas yang baik, (b) memberikan pelayanan yang baik, (c) memanfaatkan jemaat GKI Pamulang, (d) memanfaatkan karyawan GKI ataupun Lentera, (e) membentuk kepengurusan untuk mengawasi pelayanan kesehetan tersebut, serta (f) membuat program Lentera Peduli yang berinteraksi langsung dengan masyarakat.

\section{Tactic}

GKI Pamulang dalam memberikan pelayanan kesehatan ini, dimulai dari memberikan pelayanan dokter umum dan gigi, obat-obatan generik, memberikan tempat berobat yang layak seperti gedung gereja yang sudah direnovasi menjadi klinik, menciptakan suasana kekeluargaan bagi pasien dan karyawan agar pelayanan yang diberikan kepada pasien tetap baik, dan lain sebagainya. GKI Pamulang berusaha untuk menyediakan segala fasilitas dan segala ketentuan yang harus dipenuhi untuk menjadi sebuah klinik yang layak.

\section{Evaluation}

GKI Pamulang melakukan evaluasi secara oprasional rutin dilakukan setiap kali dilakukannya briefing. Evaluasi ini sangat membantu bagi GKI Pamulang, dalam meningkatkan mutu pelayanan yang dimana perlu disesuaikan dengan kemampuan GKI Pamulang sebagai gereja.

\section{DAFTAR PUSTAKA}

Ayenda, R. 2014. Pemberdayaan Petani Kedelai Hitam di Sumbermulyo, Bambanglipuro, Bantul, Melalui Peran Corporate Social Responsibility PT.Unilever Indonesia Tbk. Ugm.ac.id. Dapat diakses melalui http://etd.repository.ugm.ac.id/index.php?mod=penelitian_detail\&sub=PenelitianDetail \&act=view\&typ=html\&buku_id=67358

Bata, Arifiin \& Darmawansyah. 2013. Hubungan Kuakitas Kesehatan Dengan Kepuasan Pasien Pengguna Askes Sosial Pada Pelayanan Rawat Inap di RSUD. Unhas.ac.id. Dapat diakses melalui http://repository.unhas.ac.id/bitstream/handle/123456789/5681/JURNAL.pdf?sequence $=1$

Bungin, B. 2010. Penelitian Kualitatif - Komunikasi, Ekonomi, Kebijakan Publik, dan Ilmu Sosial Lainnya. Cetakan ke-4. Jakarta: Prenada Media Group.

Burke, E. 1999. Corporate Community Relations. Cetakan ke-1. Praeger Publishers.

Corputty,Kusnanto \& Lazuardi. 2013. Dampak Kebijakan Pelayanan Kesehatan Gratis Terhadao Kepuasan Pasien Dalam Menerima Pelayanan Kesehatan Puskesmas di Kota 
Ambon. Dapat diakses melalui https://idl-bncidrc.dspacedirect.org/bitstream/handle/10625/54046/IDL-54046.pdf?sequence=1

Creswell. 2013. Research Design Pendekatan Kualitatif, Kuantitatif, dan Mixed. Yogyakarta : Pustaka Pelajar

Dachlan, M. 2015. Dinamika Pendirian Gereja Kristen Songka dan Gereja Toraja Jemaat Maranny di Kota Palopo. Dapat diakses melalui https://blasemarang.kemenag.go.id/journal/index.php/smart/article/view/230

Denzin \& Lincoln. 2009. Handbook of Qualitative Research. Cetakan ke-1. California: Sage Publication.

Devita \& Sumartono. 2010. Hubungan Manfaat Kegiatan Community Relations Dengan Citra Perusahaan Pt. Indah Kiat Pulp \& Paper Tbk. Pada Masyarakat Kragilan Serang Banten. esaunggul.ac.id. Dapat diakses melalui http://www.esaunggul.ac.id/article/hubunganmanfaat-kegiatan-community-relations-dengan-citra-perusahaan-pt-indah-kiat-pulppaper-tbk-pada-masyarakat-kragilan-serang-banten/

Fauzi, R. 2016. Upaya Multinasional Corporations Pt Chevron Pasifik Indonesia Dalam Mempertahankan Citra Baik Di Masyarakat. Diperoleh dari: http://repository.umy.ac.id/bitstream/handle/123456789/7791/Jurnal\%20HI.pdf?sequen $\mathrm{ce}=1 \&$ is Allowed $=\mathrm{y}$

Haniy \& Darmawan. 2013. Analisis Kepentingan Aktor dan Penyebab Konflik Perizinan Pembangunan Rumah Ibadah, Studi Kasus: Gereja Kristen Indonesia Bakal Pos Taman Yasmin tahun 2002 - 2012. ui.ac.id. Dapat diakses melalui http://www.lontar.ui.ac.id/naskahringkas/2015-08/S-Sakinah\%20Ummu\%20Haniy

Imanuelo,M. 2010. Tinjauan Umum Agama Kristen Dan Nilai-Nilai Kekristenan. Uajy.ac.id. Dapat diakses melalui http://e-journal.uajy.ac.id/2407/3/2TA12257.pdf

Iriantara, Y. 2004. Community Relations: Konsep dan Aplikasinya. Cetakan ke-1. Bandung: PT. Remaja Rosdakarya Offset.

Iskandar, S. 2016. Pelayanan Kesehatan Dalam Meningkatkan Kepuasan Masyarakat Di Rumah Sakit Panglima Sebaya Kabupaten Paser. unmul.ac.id. Dapat diakses melalui http://ejournal.ip.fisip-unmul.ac.id/site/wpcontent/uploads/2016/06/JURNAL\%20SOLEH\%20ISKANDAR\%20(06-15-16-01-4139).pdf

Klenke, K. 2016. Qualitative Research in the Study of Leadership USA: Leadership Development Institute (LDI)

Lattimore, Baskin, Heiman, Toth. 2007. Public Relations The Profession and the Practice. McGraw-Hill Company.

Miles \& Huberman. 1994. SAGE Publication, Inc.

Moore. 2004. HUMAS Membangun Citra dengan Komunikasi. Cetakan ke-1. Bandung. PT. Remaja Rosdakarya.

Moleong, L. 2010. Metode Penelitian Kualitatif. Cetakan ke-28. Bandung. PT. Remaja Rosdakarya.

Moleong, L. 2016. Metode Penelitian Kualitatif. Cetakan ke-35. Bandung. PT. Remaja Rosdakarya. 
Mufid, A. 201). Kasus - kasus Aktual Kehidupan Keagamaan di Indonesia. Cetakan ke-1. Jakarta : Kementerian Agama RI, Badan Litbang dan Diklat, Puslitbang Kehidupan Keagamaan, 2014

Nazir, M. 2003. Metode Penelitian. Cetakan ke-5. Jakarta: Penerbit Ghalia Indonesia

Pertiwi \& Perlindungan. 2016. Strategi Community Relations dalam Membentuk Perilaku Khalayak. Kalbis.ac.id. Dapat diakses melalui http://research.kalbis.ac.id/Research/Files/Article/Full/825ALNOIH2K7MYTJYBG024 382.pdf

Prastiwi, A. Desember 22, 2016. The Economist: Kasus Ahok Ujian bagi Toleransi di Indonesia. Liputan6.com. Dapat diakses melalui https://www.liputan6.com/global/read/2685235/the-economist-kasus-ahok-ujian-bagitoleransi-di-indonesia

Prijono, D. 2015. Aktivitas Community Relations Pt Pfizer Indonesia Dalam Membina Hubungan Baik Dengan Komunitas. Mercubuana.ac.id. Dapat diakses melalui http://download.portalgaruda.org/article.php?article=435845\&val=9230\&title=AKTIVI TAS\%20COMMUNITY\%20RELATIONS\%20PT\%20PFIZER\%20INDONESIA \%20 DALAM\%20MEMBINA\%20HUBUNGAN\%20BAIK\%20DENGAN\%20KOMUNIT $\underline{\mathrm{AS}}$

Prihastiti \& Kusumastuti. 2012. Analisis Pembentukan Citra Perusahaan Listrik Negara Melalui Implementasi Community Relations. Ipb.ac.id. Dapat diakses melalui http://repository.ipb.ac.id/jspui/bitstream/123456789/54429/1/I12npr.pdf

Putra, Y. 2014. Program Csr Sebagai Penerapan Community Relations: Studi Kasus "Living With Hiv" Oleh Salah Satu Bank Internasional Yang Memiliki Cabang Pusat Di Indonesia. Unair.ac.id. Dapat diakses melalui http://www.journal.unair.ac.id/filerPDF/commd2face04eafull.pdf

Ruslan, R. 2014. Manajemen Public Relations \& Media Komunikasi: Konsepsi dan Aplikasi. Cetakan ke-12. Jakarta: PT. Rajagrafindo Persada.

Rivers, W. 2003. Media Massa \& Masyarakat Modern. Cetakan ke-3. Jakarta. Kencana

Salingbagi, S. 2014. Definisi Pelayanan Sosial. Salingbagi.com. Dapat diakses melalui http://www.salingbagi.com/2014/07/definisi-pelayanan-sosial.html

Smith, R. 2013. Strategy for Public Relations. Lawrence Erlbaum Associates,Inc.

Sinaga, Intan, \& Evilia. 2015. Strategi Community Relations Pt. Telekomunikasi Indonesia (Pt. Telkom, Tbk) Dalam Usaha Peningkatan Pemanfaatan Internet Untuk Usaha Kecil Menengah Melalui Kegiatan Broadband Learning Centre. Dapat Diakses Melalui Http://Journal.Wima.Ac.Id/Index.Php/Komunikatif/Article/View/771

Soekanto, S. 2012. Sosiologi Suatu Pengantar. Cetakan Ke-44. Jakarta. Rajawali Pers.

Sugiyono. 2009. Memahami Penelitian Kualitatif. Cetakan Ke-5. Bandung: Alfabeta.

Sulistiowati, R. 2015. Upaya Peningkatan Kesejahteraan Sosial Lansia Melalui Pos Pelayanan Sosial Lanjut Usia (Pps Lu) Di Desa Srimartani, Kecamatan Piyungan, Kabupaten Bantul. Dapat Diakses Melalui File:///C:/Users/Sjilaa\%20qirsten/Downloads/578-1057$\underline{1-S m . P d f}$ 
Sumbung, Suman, Hidayat, \& Kindangen. 2012. Peran Gereja Dalam Peningkatan Ekonomi Masyarakat Di Tomohon Sulawesi Utara. portalgaruda.org. Dapat diakses melalui download.portalgaruda.org/article.php?...Peran\%20Gereja\%20Dala.

Syarifuddin \& Suryanto. 2016. Public Relations. Cetakan ke-1. Yogyakarta: Andi Offset.

Taurissa, A. 2017. Evaluasi Program Community Relations Perusahaan X. media.neliti.com. Dapat diakses melalui https://media.neliti.com/media/publications/186371-ID-evaluasiprogram-community-relations-per.pdf

Thomas. 2014. Sejarah Singkat GKI Pamulang. Gki-pamulang.org. Dapat diakses melalui http://www.gki-pamulang.org/tentang_kami.html

Tolong, M. 2010. Strategi Komunikasi Sekolah Tinggi Theologia Jaffray Makassar Terhadap Masyarakat Sekitar. neliti.com. Dapat diakses melalui https://media.neliti.com/media/publications/137477-ID-strategi-komunikasi-sekolahtinggi-theol.pdf

Yudarwati, A. 2004. Community Relations: Bentuk Tanggung Jawab Sosial Organisasi. Uajy.ac.id. Dapat diakses melalui https://ojs.uajy.ac.id/index.php/jik/article/view/164

Wilcox, D. 2005. Public Relations: Strategies and Tactics. Pearson Education, Inc. 